BULLETIN Bulletin hispanique

HISPANIQUE Université Michel de Montaigne Bordeaux

$120-2$ | 2018

Varia

\title{
Para memoria de los tiempos venideros: mensajes ocultos en la escultura religiosa española de los siglos XVII y XVIII
}

Pour mémoire des temps à venir : messages cachés dans la sculpture religieuse espagnole du XVII ${ }^{e}$ et du XVIII ${ }^{e}$ siècles

To be remembered by times to come: the messages hidden in the Spanish religious sculpture of the $17^{\text {th }}$ and $18^{\text {th }}$ centuries

\section{Concepción Peña-Velasco}

\section{(2) OpenEdition}

\section{Journals}

Edición electrónica

URL: https://journals.openedition.org/bulletinhispanique/7074

DOI: 10.4000/bulletinhispanique.7074

ISSN: 1775-3821

Editor

Presses universitaires de Bordeaux

Edición impresa

Fecha de publicación: 10 diciembre 2018

Paginación: 599-614

ISBN: 979-10-300-0337-6

ISSN: 0007-4640

\section{Referencia electrónica}

Concepción Peña-Velasco, «Para memoria de los tiempos venideros: mensajes ocultos en la escultura religiosa española de los siglos XVII y XVIII», Bulletin hispanique [En línea], 120-2 | 2018, Publicado el 02 enero 2022, consultado el 08 enero 2022. URL: http://journals.openedition.org/bulletinhispanique/ 7074 ; DOI: https://doi.org/10.4000/bulletinhispanique.7074 


\section{Para memoria de los tiempos venideros: mensajes ocultos en la escultura religiosa española de los siglos XVII y XVIII ${ }^{1}$}

\section{Concepción Peña-Velasco \\ Universidad de Murcia}

Pour mémoire des temps à venir : messages cachés dans la sculpture religieuse espagnole du XVII et du XVIII siècles

Larticle analyse les messages dissimulés dans les sculptures espagnoles de l'après Concile de Trente : des plus simples (les plus nombreux), avec identité de l'auteur et/ou du bienfaiteur et des indications chronologiques ou autres, jusqu'aux plus complexes.

Mots-clés: culture écrite, messages cachés, sculpture espagnole baroque

Se estudian mensajes que se escondieron en esculturas españolas realizadas en el contexto de la religiosidad posterior al Concilio de Trento : desde los más sencillos y frecuentes de autoría y/o con indicación del benefactor, cronología y otros datos, hasta los más complejos.

Palabras clave: cultura escrita, mensajes ocultos, escultura barroca española.

To be remembered by times to come: the messages hidden in the Spanish religious sculpture of the $17^{\text {th }}$ and $18^{\text {th }}$ centuries

This article studies the messages concealed within Spanish sculptures in the post-Council of Trent religious context : from the simplest and most frequent ones - with references to authorship, commission, chronology, etc - to more complex ones.

Keywords: written culture, hidden messages, Spanish baroque sculpture.

1. Este trabajo es resultado del proyecto de investigación Hispanofilia III exp. HAR201452414-C2-1-P del Ministerio de Economía y Competitividad. 


\section{Planteamiento}

Constituye el objeto de este estudio la reflexión sobre la razón de ser y el contenido de mensajes que han ido apareciendo en el interior de esculturas religiosas del Barroco español, efectuando una aproximación genérica al tema. Desde el siglo XIX, la prensa y publicaciones de carácter diverso se han hecho eco del hallazgo fortuito de anotaciones dentro de las obras, tanto en papel como inscripciones en la madera. Normalmente se han descubierto durante restauraciones acometidas en las piezas, roturas y otras incidencias. Se ha venido informando de la presencia de estas cédulas y no siempre se han conservado, transcrito o fotografiado. Se sabe de su existencia y de lo que expresan en su conjunto o parcialmente, pero a veces no se conoce con exactitud su literalidad, ni cuál ha sido su destino. De ahí que no se incorporen los textos completos en este estudio, sino solo algunos ${ }^{2}$. Los datos averiguados de este modo han sido tradicionalmente utilizados para avanzar en el conocimiento de los maestros y de sus obras. Empero, no se han analizado tanto con una visión de conjunto y desde la perspectiva de la cultura escrita. Este estudio pretende ser una primera aproximación al tema e incidirá en los datos de contenido y motivación y no en otras cuestiones, como las características de la escritura.

Estos mensajes forman un corpus importante y disperso con rasgos propios. Se han consultado cerca de una veintena. Unos son únicos o representativos en sus discursos; otros exponen devociones, curiosidades y conflictos en la cotidianeidad del trabajo. Los ejemplos no son numerosos, pero importan las microhistorias que palpitan tras las palabras. Se ha acotado en los siglos XVII y XVIII, aunque existen anteriores y posteriores. Los ejemplos escogidos pertenecen a la imaginería sacra, que por el material mayoritariamente utilizado -la madera-, el tema y otras circunstancias ejemplifican una situación particular. Se parte del contexto en el que se promueven y crean las imágenes religiosas y lo que significan; especialmente, su sentido, uso y la manera de contemplarlas y rezar. Frente a la Reforma y su actitud de mayoritario rechazo a la imagen sacra, la Contrarreforma reafirmó su necesidad y veneración. Su postura quedó expresada en la sesión 25 del Concilio de Trento, en diciembre de 1563 -De la invocación, veneración y reliquias de los Santos y las Sagradas Imágenes-, retomando premisas alegadas en concilios anteriores y reiterando en constituciones sinodales posteriores actitudes que remarcaban que había que evitar los abusos, lo indecente y lo indecoroso ${ }^{3}$. Si bien continuó la utilización fetichista de las imágenes.

2. En los casos en los que se ha podido leer al documento original, la transcripción ha respetado la ortografía.

3. Palma Martínez-Burgos García, Ídolos e imágenes. La controversia del arte religioso en el siglo XVI español, Valladolid, Universidad de Valladolid, 1990. Palma Martínez-Burgos García, «Las pautas doctrinales de la imagen devocional en el arte del Barroco», en P. M. Ibáńez Martínez y C. J. Martínez Soria (eds.), La imagen devocional Barroca. En torno al arte religioso en Sisante, Cuenca, Ediciones de la Universidad, 2010, p. 21-44. 
Además está la cuestión de la materialidad de la obra y cuanto a ella se refiere. El mensaje está unido, es inseparable y cobra sentido en y por la imagen que lo acoge. Este tipo de notas cabe unirlas a otras presentes en la escultura religiosa, como son las llamadas escrituras expuestas, que se incorporan en peanas y otros lugares accesibles a la lectura, donde lo más frecuente es que se identifique la imagen y se ofrezcan detalles sobre la pieza ejecutada. Asimismo se localizan inscripciones en huecos interiores y visibles de esculturas relicarios, que permiten reconocer los vestigios sagrados cobijados. En el ámbito urbano, la escultura pública suele valerse del pedestal para comunicar y existen esculturas de la Antigüedad, como la de Pasquino en Roma, que han sido utilizadas para acoger mensajes efímeros, generalmente satíricos, pero también denuncias y libelos. Las obras que acogen las notas analizadas componen un rico y variado conjunto de esculturas parlantes. En sentido figurado, se alude a la voz de las esculturas atendiendo a lo que expresan las inscripciones y al sonido producido por el viento en las oquedades de la materia. En la aspiración del artista subyace la intención de simular un ser vivo con capacidad para moverse y hablar y late la fascinación de la mano creadora por representar al ser animado y apropiarse de sus componentes, trascendiendo los límites entre ficción y realidad. Así, cabe recordar la ventriloquia y la existencia de imágenes cuyos cuerpos son maniquíes articulados que permiten el movimiento ${ }^{4}$.

El hecho de escribir y esconder lo que se escribe es mucho más que una anécdota. Cuanto menos es una estrategia para dar a conocer algo para memoria de tiempos ulteriores, como se declaraba en un documento que se examinará, o como oración a Dios. Como recurso narrativo proporciona claves para comprender mejor el pasado y, en concreto, lo relativo a la ejecución de las piezas escultóricas, así como a las personas e instituciones que las encargaron y a los artistas que las ejecutaron. Es una acción comunicativa escrita sin respuesta, que constituyó una práctica reiterada en algunos artífices. No se utilizó la superficie de la escultura para exponer un mensaje. Se aprovecharon los huecos interiores para custodiar una información. Por otro lado, el artificio del «manuscrito encontrado»-con frecuencia en lugares venerables- fue constante en la tradición narrativa y, por ende, en la oral y, en consecuencia, estaría en el imaginario colectivo 5 . El artista aprovechó las posibilidades de ocultación que le permitía la madera, material predominante en la imaginería religiosa española, que acaparó la mayor parte de los encargos. La costumbre de introducir mensajes es antigua. En cierto modo, se relaciona con la acción de esconder y la seducción por lo oculto, con el ritual de inicio y de finalización de las obras arquitectónicas y con la disposición encubierta de un objeto dentro de otro. En arquitectura, el acto de colocación de la primera piedra podía

4. Víctor I. Stoichita, Simulacros. El efecto Pigmalión: de Ovidio a Hitchcock, Madrid, Siruela, 2006, p. 141-146; Aura Satz \& Jon Wood (eds.), Articulate Objects: Voice, Sculpture and Performance, Oxford, Peter Lang, 2009; Katherine Ibbett, «Who Makes the Statue Speak? Louis XIV and the plainte des statues», Word and Images, no 24.4, 2008, p. 427-438.

5. Ana Luisa Baquero Escudero, «Un viejo y persistente tópico literario: el manuscrito hallado», Estudios Románicos, no 16-17, 2007-2008, p. 249-260. 
conllevar la introducción en los cimientos de cofres con medallas, monedas y manuscritos, donde constaban los datos relativos a la realización y la mención a los gobernantes. En nuestro tiempo, ciertas naves espaciales llevan sonidos e imágenes de la Tierra como memoria de nuestra existencia.

Numerosas son las investigaciones que han puesto en relación las imágenes con las palabras, desde temas genéricos hasta casos concretos ${ }^{6}$. Con frecuencia, se ha acudido a fuentes literarias que, por su carácter descriptivo y visualizador, procuran aproximaciones a cómo fueron determinadas obras de arte perdidas total o parcialmente. Igualmente, está la ilustración compañera del texto, ornamental o en relación al asunto tratado. En las artes figurativas y suntuarias, inscripciones de diferente tipo han coadyuvado a la interpretación iconográfica y proporcionado el conocimiento de autoría, lugar, fecha y personas implicadas en el encargo y pago. Además estarían las lápidas monumentales. Las investigaciones de Petrucci y Burke ${ }^{7}$, entre otros muchos, sobre la cultura escrita están aportando nuevas visiones a otras disciplinas, caso de las escrituras expuestas. En España se avanza gracias a sólidas líneas de trabajo de autores como Viñao, Bouza y Castillo ${ }^{8}$. Las cédulas aquí estudiadas han ido publicándose en investigaciones, que se citarán, sobre escultores y sobre restauración, así como en la prensa.

\section{De la escultura al mensaje/ Del mensaje a la escultura}

El acercamiento realista ha sido una constante en la escultura religiosa espańola y las imágenes de vestir y la tradición del uso de la policromía con carnaciones y estofados favorecieron la imitación del natural. En el Barroco, la intención de simular una imagen viva y sensible se reforzó con el uso de aditamentos como cabello, pestañas, uñas, ojos de cristal, telas encoladas y riqueza de ajuares, especialmente marianos, con prendas y joyas que lucían las imágenes y variaban conforme a los tiempos litúrgicos y festividades. En 1603 en la escritura de obligación para esculpir el Cristo de la Clemencia de Martínez Montañés, se le exigió que estuviera vivo, con ojos atentos y como si hablase

6. Cabe recordar Meyer Schapiro, Palabras, escritos e imágenes. Semiótica del lenguaje, Madrid, Encuentro, 1998. Víctor I. Stoichita, Pintura y visión religiosa en el Siglo de Oro español, Madrid, Alianza, 1996.

7. Textos emblemáticos son: Armando Petrucci, Alfabetismo, escritura, sociedad, pról. Roger Chartier y Jean Hébrard y trad. Juan Carlos Gentile Vitale, Barcelona, Gedisa, 1999 y Peter Burke (ed.), New Perspectives on Historical Writing, Pennsylvania, The Pennsylvania State University Press, 1992.

8. Véase la síntesis sobre investigaciones en la cultura escrita de Antonio Castillo Gómez, «Introducción ¿Qué escritura para qué historia?», en A. Castillo (ed.), Culturas del escrito en el mundo Occidental. Del Renacimiento a la Contemporaneidad, Madrid, Casa de Velázquez, 2015, p. 1-16. Antonio Viñao Frago, Leer y escribir: historia de dos prácticas culturales, México, Fundación Educación, Voces y Vuelos, 1999. Fernando Bouza, Corre manuscrito. Una historia cultural del Siglo de Oro, Madrid, Marcial Pons, 2001. 
al devoto que rezara a sus pies ${ }^{9}$. Como manifiesta Stoichita ${ }^{10}$, simulacro es el término que define este tipo de representación, usando una palabra repetida por las fuentes en esos siglos y remitiendo a Platón y a su distinción de dos formas de fabricar imágenes: copia y simulacro. Simulacro se relaciona con lo misterioso y se adecúa más a la devoción, al buscar la semejanza e imitación del ser y del Dios evocado. La escultura, con su corporeidad y sus valores táctiles, simula más el natural que la pintura con la bidimensionalidad. La percepción que el fiel experimentaba de la imagen escultórica como ser real o como aparición se afianzó en el caso de los santos españoles canonizados en esos siglos, que habían vivido en tiempos no muy lejanos y cuya vera efigie estaba en el imaginario del devoto. El artista plasmó los rasgos físicos auténticos de tales santos, conocidos por descripciones, grabados, cuadros y, a veces, por mascarillas. De este modo al valor protector y taumatúrgico de las imágenes de culto, se unió la dimensión de cercanía. Por ende a algunas imágenes se les concedieron indulgencias, de forma que el devoto las alcanzaba rezándoles.

La escultura se erige en objeto contenedor de misterios y elementos ocultos y atesora historias ańadidas. Como la estructura de la caja china, introduce una cosa dentro de otra, una escrita y otra esculpida. Además del relato en el relato y de la escultura en la escultura, están el relato en la escultura y la escultura en el relato. Literatura y arte han mantenido una interconexión constante. Desde la célebre locución horaciana Ut pictura poesis, los discursos artísticos y literarios se han relacionado, pero han sido la pintura y la poesía las que tradicionalmente se han vinculado con más intensidad. En otro sentido, esconder algo en la escultura es una práctica que se constata en otros momentos, países, culturas y religiones, aunque en el mundo católico adquiere connotaciones propias. En esculturas sagradas de otras confesiones se han encontrado semillas, ofrendas, manuscritos y, recientemente, la momia de un monje dentro de un Buda ${ }^{11}$. A veces se accede a los objetos depositados moviendo o activando en la escultura algún resorte que permite acceder a su interior, pero esto no se ha constatado que exista en los casos analizados. Las cédulas e inscripciones localizadas en las obras del Barroco español conforman un conjunto singular e inaccesible, que ofrece información sobre la imagen y sobre las personas que las hicieron y estuvieron tras los encargos. Se trata de actos de escritura, como define Fraenkel ${ }^{12}$, pero no se buscó la visibilidad, ni la lectura inmediata. El manuscrito se introducía durante el proceso de realización de la pieza y en ocasiones se pusieron otros

9. Domingo Sánchez Mesa, Historia del Arte en Andalucía. VII. El arte del Barroco: Escultura, Pintura, Sevilla, Gever, 1991, p. 166. Xavier Bray (ed.), The Sacred Made Real: Spanish Painting and Sculpture 1600-1700, cat. exp., London, National Gallery, 2009.

10. Víctor I. Stoichita, Simulacros... op. cit., p. 11.

11. http://www.nationalgeographic.com.es/articulo/historia/actualidad/10017/una_ estatua_buda_encierra_momia_monje.html Consulta 8 enero 2015.

12. Béatrice Fraenkel, «Actes d'écriture : quand écrire c'est faire», Langage et société, no 3 , 121-122, 2007, p. 101-112. http://www.cairn.info/revue-langage-et-societe-2007-3-page-101. htm Consulta 3 enero 2016. 
con posterioridad para indicar restauraciones y otras acciones, erigiéndose la escultura en custodio y protector de la información.

Hay diferentes tipos de mensajes, pues diversas son las situaciones y fines que los generaron y muchas las maneras posibles de aproximarse al tema. Cabría considerar quién los redacta o atender a su contenido. Si bien proponer una sistematización es complejo y llevaría a equívoco, pues queda mucho por estudiar. Son textos de gran interés con rasgos propios que se caracterizan por su corta extensión y concisión, por disponer de mayor libertad de expresión y por ser un testimonio vivo de la sociedad y de las mentalidades. Habitualmente se usaron papeles de pequeño formato y, en general, se requirió el folio recto para escribir, aunque a veces el texto continuó en el verso, donde se añadió alguna otra anotación. Al permanecer escondido y, a veces, al incorporarse pérfidamente, el tenor del mensaje no estuvo sujeto a censura y entrañó situaciones comunicativas que permitieron una franqueza que, de otra manera y con un receptor de su tiempo, no habría sido posible. No circularon, ni se concibieron para ser leídos en el momento de la redacción, ni, quizá, nunca. Estas prácticas de escritura han dado como resultado un patrimonio documental de gran interés, que constituye una fuente primaria útil para conocer mejor los componentes devocionales y los complejos procesos de realización de las obras de arte y a sus protagonistas, así como las relaciones sociales y profesionales, conflictos y sentimientos que engendraron. Este tipo de manifestación aporta una versión escueta de los hechos que trasciende de la proporcionada por otros documentos sujetos a formalismos oficiales y consuetudinarios, como los notariales -escrituras de obligación, cartas de pago, testamentos o inventarios de bienes de artistas y mecenas-, libros de fábrica - desembolsos por material y ejecución-, judiciales - pleitos- y, excepcionalmente, libros de cuentas de los maestros. Estos documentos han centrado la atención de investigadores en busca de datos sobre las piezas y sobre quienes las fabricaron y, más recientemente, se han completado con aportaciones sobre escrituras expuestas.

A veces los textos responden a las convenciones de lápidas conmemorativas e inscripciones votivas. Concluyendo el Antiguo Régimen, Ponz sintetizó la postura de los ilustrados respecto a las monumentales, resaltando el beneficio que resultaba de su utilización y la necesidad de que estuvieran «a la vista del mundo» y se redactasen por "personas doctas», con propiedad, claridad y brevedad ${ }^{13}$. Ciertamente que ciertos aspectos también se manifiestan en las cédulas, pero su lenguaje suele ser menos formal y no precisa de una corrección tan atenta como consecuencia de su destino. El manuscrito puede presentar tachones, borrones y erratas. Por ende, se reutilizaron papeles usados, con bosquejos y apuntes de contabilidad u otro tipo. En el aparecido en el Ecce Homo de La Roldana para la Catedral de Cádiz se incluyen anotaciones numéricas y tres dibujos a lápiz y sombreados de perfil de la parte del rostro desde la nariz hasta la barbilla, así como la silueta frontal de narices y labios

13. Se cita de la edición de Antonio Ponz, Viaje de España 1, Madrid, Aguilar, 1988, p. 644645. 
cerrados, que no se corresponden con la imagen de Cristo esculpida ${ }^{14}$. En ocasiones, el texto es intimista. Manifiesta devociones, sentimientos, conflictos y malestar ante una situación injusta. Estos testimonios del agraviado evocan, con la distancia y diferencias existentes, las tablillas de maldiciones y conjuros de la Antigüedad que se ocultaban bajo tierra y que a veces se acompañaron de estatuillas y muñecos que representaban a la persona aludida.

Las notas se acostumbraban a situar en la oquedad interior de la escultura o de la peana, siendo el papel y la madera los soportes comunicativos, pues además se hicieron inscripciones en las obras y hay ejemplos de coexistencia de ambos. Sánchez Mesa señala que se pusieron también en los huecos de los ojos ${ }^{15}$. Sebastián de Paz solía efectuar una anotación de autoría con otros datos en la parte interior y no visible del torso de las figuras ${ }^{16}$. Las cédulas las escribían los artistas, discípulos, benefactores, comitentes o amanuenses por voluntad de una de las partes o de varias y se podían encabezar con una cruz. Se trata de personas que se insertaban en el ámbito de la cultura escrita, pero no eran escritores. Las notas reflejan el modo en que ellos seleccionaron lo que deseaban transmitir e interpretaron lo acontecido. En un Crucificado de Francisco de Ocampo se declaraba respecto al cliente que «acordó el dicho Gaspar Pérez Torquemada meter este papel» ${ }^{17}$. Hay algún caso atípico, por ejemplo el verificado en un San Antonio Abad del retablo mayor de San Pedro en Gata. Consta que la imagen la había hecho Pedro Paz en Alcántara, siendo su hijo quien escribió la nota ${ }^{18}$. Se trata de mensajes unilaterales. Existe un emisor y un posible destinatario futuro, pero no se concibieron para una difusión inmediata, ni tuvieron respuesta. El receptor comparte información y sentimientos fuera del tiempo de creación de la escultura. Hay escasas referencias al destinatario, salvo las cédulas devocionales dirigidas a Dios. Se escribía para un lector genérico. En 1684 Luisa Roldana y su marido señalaron lo siguiente: «a todos los que esto supieren agan algunos sufrajios porque Dios perdone sus almas esto se [sic] por amor de Dios y pedimos perdón a todos los que ubieremos ofendido i nosotros perdonamos a nuestros enemigos» ${ }^{19}$. En 1757 una nota concluía con «Digan Requiescat in pace Amen» y, en 1785, otra

14. Documento recogido por Alfonso Pleguezuelo, «Una nueva obra de Luisa Roldán: El Ecce Homo de la Catedral de Cádiz», $A B C, 14$ diciembre 1984, p. 79, y Ma Victoria García Olloqui, La Roldana, Sevilla, Guadalquivir, 2000, p. 79.

15. Domingo Sánchez Mesa, op. cit., p. 46.

16. José Antonio Ramos Rubio, "Dos obras inéditas del escultor Sebastián de Paz», NORBAARTE, $\mathrm{n}^{\circ} 10,1990$, p. 245-246.

17. Véase el comentario con la referencia y digitalización del documento que, con motivo del aniversario de esta obra, efectuó Julio Domínguez Arjona, «La Sevilla que no vemos. Breve cronología del Cristo del Calvario», 12 enero 2012, http://www.galeon.com/ juliodominguez/2012/calvario.html Consulta 1 mayo 2015.

18. Se dio noticia a finales del siglo XIX y, mucho después, se documentó el pago de varias imágenes al escultor y el traslado (José María Torres Pérez, El retablo mayor de la iglesia de San Pedro de Gata: una obra del escultor Pedro de Paz y del pintor Pedro de Córdoba, Cáceres, Diputación Provincial de Cáceres, 1985, p. 17-18).

19. Ma Victoria García Olloqui, op. cit., p. 79. 
con vivan «Jesús, María y Joseph y vivan todos los santos de nuestra devoción y biba San Pasqual Bailón y todos los Bienhechores con el Señor Sacramentado. Amén» ${ }^{20}$.

La referencia al templo o ciudad donde se ubicaba la imagen no siempre se manifestaba. La propia obra lo indicaba con su presencia, aunque vaivenes históricos la hubieran hecho transitar. En ocasiones, se alude a la capilla del comitente y, a veces, de la familia, destacando la mención al linaje en un contexto en el que solía dominar el personalismo ${ }^{21}$. Si el maestro tenía el taller en un núcleo urbano diferente al destino de la imagen, se podía advertir la localidad donde realizó la pieza. Pedro Paz efectuó el citado San Antonio Abad para Gata en Alcántara, José Ortega un San Blas para Bullas en Caravaca y, en esta villa santiaguista, Marcos Laborda hizo Las Angustias para Cehegín. La indicación cronológica va indistintamente al comienzo o al final del texto, incluso en el verso del papel. Se informa de cuándo se "principió», aunque lo más frecuente es mencionar la conclusión o la entrega. Pueden constar varias datas y, excepcionalmente, la del contrato. Laborda aludió a la festividad de San Pascual Bailón, día en que comenzó Las Angustias, y Sebastián de Paz a la fecha en que trabajaba ${ }^{22}$.

En general se hace memoria de los artistas y de las personas que tomaron parte de diferente modo en el encargo, así como de las autoridades civiles -desde el rey a las locales- y eclesiásticas -papa, obispo, párroco, jerarquías de comunidades monásticas y hermandades, cargos de los territorios de las órdenes militares, etc.-. La enumeración cambia según el caso. Si en 1612 en el Crucificado de Ocampo se puso que reinaba Felipe III y era arzobispo sevillano Pedro de Castro, en 1684 en el Ecce Homo de La Roldana se citó a Carlos II, en «Francia Luis désimo tercio» -el monarca era Luis XIV-y al prelado hispalense Ambrosio Ignacio Spínola y Guzmán, señalando que había muerto unos meses antes, pues eran tiempos de sede vacante. A mediados del siglo XIX se halló en la peana de una Virgen de las Maravillas para el convento franciscano de Cuevas de Almanzora una cédula que citaba a Francisco I y decía así:

Hizo esta Imagen de N. S. de las Maravillas Joseph Ortega para la Villa de Cuevas, colocada en el Convento de N. P. S. Francisco. Se hizo a diligencia de Fray Francisco de Molina, Lector Jubilado de la misma orden. Gobernaba la Iglesia N.S. Smo. Padre

20. Andrés Baquero Almansa, Catálogo de los Profesores de las Bellas Artes Murcianos, con una introducción histórica, Murcia, Sucesores de Nogués, 1913, p. 256. Francisco E. López Soldevila, Francisco Javier Bernal Casanova, José Francisco López Martínez y Arturo Serra Gómez, «La restauración de Las Angustias de Cehegín: nuevas aportaciones documentales a la escultura regional», Imafronte, no 18, 2006, p. 151-166.

21. Aunque en lo conocido hasta ahora no proliferan las alusiones a la familia y linaje, no sería excepcional que hubiera referencias. En otros casos, existen. Véase Antonio Cea Gutiérrez, "Cuando las cosas hablan: devoción, patrimonio y mecenazgo en la sociedad salmantina», en R. Robledo (coord.), Historia de Salamanca VI. Recapitulación, Fuentes, Índices, Salamanca, Centro de Estudios Salmantinos, 2013, p. 355-429.

22. "HAZÍA ESTA FIGURA EN ALCÁNTARA SEVASTIÁN DE PAZ, AÑO DE MDCXXI. A XXVII DE FEBRERO» (José Antonio Ramos Rubio, op. cit., p. 245). Francisco E. López Soldevila et al., op. cit., p. 162. 
Benedicto XIII. Reynaba en España Fernando VI. En el Imperio Francisco Estevan I Gran Duque de Lorena. Octubre 26 de 1757. Joseph Ortega [firmado]. Los Agentes Fray Antonio Alarcón, Fray Andrés Gallardo, en Caravaca donde se hizo la Santa Imagen. Digan Requiescat in pace $\mathrm{Amen}^{23}$.

En 1785 en el caso citado de Cehegín se efectuó una extensa enumeración de personas que iban desde los comisarios de la imagen -entre ellos el capellán de la ermita-, pasando por el artista, sus progenitores y maestro, para terminar con «reinaba Carlos tercero y en Roma el Santísimo Padre Pío Sexto» y la fórmula final ritual «Dios guarde». José Ortega hizo en 1765 un santo a «devoción de su Mayordomo abacial Antonio de Rebeller, presbítero. Siendo Pontífice Clemente XIII; Obispo y Presidente de Castilla Don Diego de Roxas; Rey de España Don Carlos 30; Vicario en propiedad Don Ignacio Joseph de Guzmán, Gobernador y Capitán á guerra Don Antonio de Aranz y Alcalde mayor Don Andrés de Quesada » ${ }^{24}$.

En contadas ocasiones se especificó el precio de la obra. José Sáez reveló las pérdidas que tuvo en el retablo mayor de los jesuitas de Caravaca y Juan de Mesa desglosó en un San Francisco Javier el coste de la imagen en blanco y su policromía, así como del retablo sevillano donde se ubicó y su dorado ${ }^{25}$. Excepcionalmente, lleva un Agnus Dei, como la cédula del Crucificado de 1612 de Francisco de Ocampo. Tanto en el recto como en el vuelto del papel se menciona la incorporación de «un pedacito del Linum Crucis» ${ }^{26}$. La escultura asume aquí el valor añadido de ser relicario, pero se distingue de las habituales esculturas relicario en tanto que los vestigios sacros no están visibles para su veneración.

En relación a por qué se escribe, es complicado saber las motivaciones personales o colectivas que se tuvieron para redactar la notas analizadas y entender el contexto en el que se originaron. Cada caso acarrea su historia y su complejidad. Con frecuencia se declara que la imagen se hizo por devoción del comitente o del artista, pero apenas se insinúan las razones que llevaron a transmitir un mensaje. En este sentido, destaca que, en el citado Crucificado de Ocampo, se explicase que "para memoria de los tiempos benideros en el gueco» de la escultura se acordó poner la nota ${ }^{27}$. Es decir, junto a motivaciones

23. El papa era Benedicto XIV, bien fue una confusión o una errata en la transcripción (Miguel Flores González-Grano de Oro, «El escultor caravaqueño José Ortega», Boletín de la Junta de Patronato del Museo Provincial de Bellas Artes de Murcia, no XIII, 1935, p. 74-77, cita p. 74).

24. La descubrió al restaurarla el escultor Sánchez Araciel y la volvió a colocar en su lugar. La publicó Baquero, señalando que corregía la ortografía (Andrés Baquero Almansa, op. cit., p. 256).

25. José Antonio Melgares Guerrero y Amparo Martínez Cuadrado, Historia de Caravaca a través de sus monumentos, Murcia, Caja de Ahorros Provincial de Murcia, 1981, p. 23. Juan González Luque, «La imagen de San Francisco Javier en la Iglesia de San Francisco de el Puerto de Santa María», Cruz de Guía, Marzo 2007, p. 16-19 http://www.lahornacina.com/ articulosmesa1.htm Consulta 4 enero 2016.

26. La reliquia hoy se custodia en un ostensorio (Julio Domínguez Arjona, op. cit.).

27. Ibid. 
devocionales estaría preservar la memoria de las personas y de lo acontecido. Frente al olvido de los nombres como segunda muerte al que se refiere Vasari en las vidas de artistas, las palabras salvaguardan y legitiman con el recuerdo ${ }^{28}$. El protagonismo lo tuvieron las imágenes religiosas, no las personas, y con la cédula se honraba la memoria de quienes crearon las obras, las encargaron, pagaron o regalaron, significando quiénes eran y dejando constancia de acciones que los prestigiaban. Proliferan las inscripciones de autoría, detallando a veces la profesión. No siempre se firmaron. Hay intenciones comunicativas que buscaron el reconocimiento y autoafirmación como artista; otras el desahogo y la confidencialidad para contar hechos que evidencian desencuentros entre cliente y artista o entre maestro y discípulo. En la cédula del Crucificado de la Capilla de los Ángeles de Sevilla se escribió: «Este Cristo se hizo en Sevilla año de mil y seiszientos y veinte y dos. Hízolo Andrés de Ocampo maestro escultor ${ }^{29}$. Sobre Francisco de Ocampo, sobrino del anterior, se especificaba en 1612 que era escultor de imaginería ${ }^{30}$. Mucho más extenso es el texto del Ecce Homo ya mencionado, fechado en 1684. Informa de la ejecución de la obra por parte de Luisa Roldán e incluye comentarios destacables, como que la escultora la efectuó materialmente, que era una artífice insigne y que con ella colaboró su marido: «Iso esta echura con sus manos la insigne artífise doña Luisa Roldán en conpañía de su esposo Luis Antonio de los Arcos» ${ }^{31}$. El reparto de tareas en el taller de La Roldana era conocido: ella hacía las imágenes y su cónyuge, que era dorador, las dotaban de color. Pero aquí se refleja la autoestima y lo que significa la buena escultura como síntesis de lo liberal y lo mecánico.

Con ocasión de la ejecución del retablo principal del templo de la Compañía de Jesús en Caravaca, el tallista responsable firmó una cédula mencionando a su equipo de colaboradores: «Maestro de esta obra José Sáez, vecino e hijo de Murcia, y oficiales Faustino Litrán, Bernardino del Campo, Antonio Fernández, Joaquín Flores, Damián Sánchez; el escultor José Ortega. Que todos estuvieron desde sus principios, sin otros que ayudaran ${ }^{32}$. En un San Francisco Javier del Colegio de la Compañía de Jesús sevillano, hoy en el Puerto de Santa María, localizaron en 1927 una nota que revelaba el nombre del artista Juan de Mesa, su oriundez cordobesa y su aprendizaje con Martínez Montañés ${ }^{33}$. El discipulado y filiación también se reflejan en una más amplia referencia autobiográfica contenida en la cédula de Las Angustias de Cehegín:

28. Véase George Didi-Huberman, Ante la imagen. Pregunta formulada a los fines de una Historia del Arte, Murcia, Cendeac, 2010, p. 82-84.

29. Recogido por José Hernández Díaz, «Los Ocampo, imagineros giennenses del Siglo de Oro", Boletín del Instituto de Estudios Giennenses, no 103, 1980, p. 93-115, lám. 15.

30. Ibid., lám. 16.

31. María Victoria García Olloqui, op. cit., p. 75-78. La célebre escultora de cámara de Carlos II y Felipe $V$ reiteró mediante inscripciones visibles que ostentaba esta designación en la corte.

32. José Antonio Melgares Guerrero y Amparo Martínez Cuadrado, op. cit., p. 23.

33. Juan González Luque, op. cit., José Hernández Díaz, Juan de Mesa, Escultor de Imaginería (1583-1627), Sevilla, Diputación Provincial de Sevilla, 1972, p. 68. Domingo Sánchez Mesa, op. cit., p. 72-75. 
«Marcos Laborda hijo de Pedro León de Laborda y de Juana García Navas fue discípulo de Don Joseph López» ${ }^{34}$. El mismo artista en 1794 en un San Pascual Bailón para la parroquia de Caravaca señaló que lo «hizo a su devoción» y que era «Profesor de la noble arte de escultura» ${ }^{35}$. Poco después en un busto de la Dolorosa para Santa Florentina en Murcia, escribió: «Fecit Marcus Laborda. Año de 1798, en Murcia para Don Juan Pedro Florez Nabarro Bien echor. Para la gran Reina ${ }^{36}$. Sorprende la nota datada en 1742 de la Dolorosa de Santa Catalina de Murcia de Francisco Salzillo, que no solía firmar sus obras. No se recuerda al célebre escultor, quizá porque era un maestro de prestigio con un estilo reconocible y porque, en su humildad y grandeza profesional, no le importaba que no constase su nombre, pese a que conocería el mensaje y su contenido y debió consentir en que se introdujera, al ensamblar las piezas de la escultura. En cambio se cita al párroco Juan Tomás Rojo y Alcaraz, que era comisario de la Inquisición, y al presbítero que «la pagó» y situó en la capilla, José Rodríguez Salinas, natural de Cieza y enterrado en 1761 en ella ${ }^{37}$.

Podía ser un colectivo quien pagara: «Se yzo a deboción de los fieles devotos de la billa de Ceegín y fueron los comisarios de dicha Ymagen Don Joseph Gonzáles Ortega capellán de la hermita de la Sangre de Christo donde se colocó dicha imagen $»^{38}$. Tras la canonización en 1622 de San Francisco Javier, nacido en 1506 en el antiguo Reino de Navarra, se encargó a Juan de Mesa una escultura del santo para el colegio sevillano de San Hermenegildo. En la cédula encontrada se detallaba que la mandaron hacer los «señores veinticuatro", especificando el nombre y oriundez en localidades navarras de varios de ellos, lo que pondría de manifiesto una procedencia común del santo y algunos de estos cargos concejiles y que, en la motivación devocional, pesó también el paisanaje compartido por San Francisco Javier y estas personas, que vivían, además, fuera de su tierra de origen, con lo que entrañaría de nostalgias y afectos $^{39}$.

En ciertas figuras de los belenes barrocos napolitanos surge la voluntad de un colectivo de aludir a localidades concretas. Aunque los napolitanos no eran súbditos del Rey de España a finales del XVIII cuando se documentan las piezas mencionadas -que no son imágenes de culto-, todavía pesaba la impronta cultural hispánica en este territorio, aunque las influencias fueron recíprocas y muchas figuras de belenes napolitanos se encuentran en colecciones

34. Francisco E. López Soldevila et al., op. cit., p. 162-163.

35. Julián Martínez Iglesias, "La Parroquial del Salvador de Caravaca», Boletín de la Junta de Patronato del Museo de Bellas Artes, Año VI, 1928, n. 6, s.p.

36. Centro de Restauración de la Comunidad Autónoma de Murcia https://www.youtube. com/watch?v=Sqc8ZwerWbA Consulta 8 mayo 2015.

37. Fue encontrado, igualmente, por el Centro de Restauración murciano (Noticias de Europapress, junio de 2014 http://www.europapress.es/murcia/noticia-manuscritohallado-dolorosa-santa-catalina-permite-datar-obra-salzillo-1742-20140618130808.html Consulta 30 julio 2014).

38. Francisco E. López Soldevila et al., op. cit.

39. Juan González Luque, op. cit. 
y museos españoles. Entre el repertorio de escenas de la vida urbana y rural de los belenes de la Colección García de Castro del Museo Nacional de Escultura en Valladolid y del Museo Salzillo en Murcia, se encuentran figuras que llevan una cédula con una indicación geográfica de origen, localizada entre la estructura de estopa y alambre que conforma el cuerpo y las prendas que portan, pues no son piezas de madera. Los papeles no se esconden en emplazamientos inaccesibles, aunque no están en sitios visibles. Así, en una figura masculina del belén expuesto en Murcia pone «Paese di Craco, Provincia di Matera» y, en una femenina, otro escrito delata la pertenencia a «Paese di Viggiano. Provincia di Potenza». En otros casos es «Terra di Lavoro» y hay más notas identificativas en otras figuras pertenecientes a belenes napolitanos. En el libro de Morelli Biografia degli uomini illustri del Regno di Napoli, editado en 1822 , se indica que ciertas obras se efectuaron en la década de los ochenta para ser enviadas al monarca español por su hermano, remitiendo una pareja «galantemente vestida» de cada país del reino ${ }^{40}$. Catello señala que, según las exigencias y los casos, algunas figurillas aluden a costumbres y tradiciones de las provincias consignadas por lo que visten, portan o simulan hacer; proliferando la producción de prendas populares de las diferentes localidades del antiguo reino napolitano con destino a belenes, como también se manifestaron las singularidades indumentarias locales en la porcelana de la época ${ }^{41}$.

Junto a indicaciones temporales y espaciales y a la memoria individual y colectiva, se encuentran datos de carácter descriptivo, conmemorativo y contextualizador, con alusiones a la ejecución, encargo, pago y hechos y personas considerados dignos de ser recordados. En contadas ocasiones de narrativas autobiográficas, el artista presenta testimonios íntimos, con sus contradicciones y paradojas. Este tipo de egodocumentos se originaron, a veces, a partir de vivencias amargas ${ }^{42}$. La voz narradora de los hechos podía reflejar el estado emocional, pues quien escribía sabía que la escultura ocultaría el mensaje y velaría por la continuidad de un secreto, que sería descubierto o no por un lector futuro. Las experiencias relatadas, al producirse normalmente en el ámbito privado y evidenciar situaciones originadas en la cotidianeidad del taller y trato con el cliente, son más difíciles de averiguar y su transmisión pudo quedar en círculos restringidos. Descubren las siempre complejas relaciones humanas, colmadas de fricciones y desengaños, y hablan de la sociedad del momento. Los textos conservados de esta índole son escasos. En una nota contenida en el

40. Tales figuras se han venido identificando con algunas conservadas en Valladolid y Murcia (Jesús Urrea et al., El Belén napolitano del Museo Nacional de Escultura, Valladolid, Museo Nacional de Escultura, 2000, p. 15-18. Carmelo García de Castro Márquez y Emilio García de Castro Márquez, Un Belén Napolitano del siglo XVIII, Madrid, Planeta, 2012, p. 20).

41. Elio Catello, «Il Presepe Napoletano del Settecento», Il nuovi Quaderni dell 'Antiquariato, no 23, 1991, p. 44-48. Nicola Spinosa et al., El Belén Napolitano: El Arte del Belén entre Nápoles y España, cat. exp., Salamanca, Caja Duero, 2007.

42. Sobre los egodocumentos, véase, entre otros, Winfried Schulze, «Sobre el significado de los ego-documentos para la investigación de la Edad Moderna», Cultura escrita y sociedad, no 1 , 2005, p. 110-113. 
retablo de los jesuitas de Caravaca ya citado, el maestro responsable no ocultó su desazón y se quejó de pérdidas económicas, descalificando a una de las personas encargadas del seguimiento del trato. Sintió la necesidad de relatar lo vivido, expresó su verdad y manifestó su malestar. El texto comenzaba de la forma siguiente:

Se ajustó esta obra de la Compañía por el Padre Rector José Mota, natural de la ciudad de Chinchilla, y su procurador el Hermano Francisco Lluste el año 1756. Se acabó por muerte de este procurador, por Nicolás Prado, el hombre más mísero del mundo, quien me ha hecho perder muchos reales hasta seis mil. Y por ausencia de este Rector José Mota, vino el padre Eugenio Megías, quien es Rector al presente, y Pontífice Clemente 13, Rey Fernando 6, Vicario Don Ignacio Guzmán, Gobernador Don Diego de Ciria ${ }^{43}$.

En Las Angustias de Cehegín, el hallazgo de una cédula replanteó la autoría. La nota no deja lugar a dudas al determinar que «el artífice que la yzo fue Marcos Laborda $»^{44}$. Además, una inscripción interior lo reitera. Laborda afirmaba haber sido discípulo de José López, uno de los dos maestros con carta de aprendizaje documentada con Francisco Salzillo. El problema estaría en que en la Memoria de hechuras de Roque López, el otro escultor formado con Salzillo, se aludía a la ejecución por parte de este último de la que parece la misma imagen por fecha $-1785-$, tema y destino ${ }^{45}$. Difícilmente hubo error en la transcripción del libro de cuentas, cuyo original está en paradero desconocido, pues la coincidencia es clara. ¿Estaría Marcos Laborda trabajando en el taller de Roque López e incorporó la nota a espaldas del maestro principal?. ¿Formó con él una compañía temporal y uno se vinculó al diseño y a efectuar las partes más destacadas de la figura y el otro a la ejecución del resto y quiso dejar constancia de ello?. José López había muerto en 1781 y Laborda quizá entrase a trabajar con Roque López, habida cuenta de que en él recayeron, tras el fallecimiento de Salzillo en 1783, numerosos encargos. Es posible que López necesitara mano de obra cualificada, pues Laborda cumplió 33 ańos por entonces y era ya maestro. También Laborda pudo hacer en solitario la escultura. De modo que los interrogantes interpretativos sobre la obra no han cesado.

Hay cédulas de contenido devocional, que delatan la religiosidad de ciertos maestros y la creencia en la eficacia de rezar a las imágenes, especialmente de Cristo en la pasión y su madre. Estas plegarias se relacionan con prácticas de piedad que muestran que el artífice se instruía espiritualmente para ser inspirado y conformar una obra adecuada que avivase la devoción, como revela un manuscrito de Nicolás de Bussy que se citará. Palomino afirmaba que Gregorio Fernández se preparaba «con la oración, ayunos, penitencias, y

43. José Antonio Melgares Guerrero y Amparo Martínez Cuadrado, op. cit., p. 23. Concepción de la Peńa Velasco, «El valor y el sentido de la palabra en el retablo español. De finales del Gótico a comienzos del Neoclasicismo», Tonos digital, no IV, 2002 https://www.um.es/tonosdigital/ znum4/estudios/retablo.htm Consulta 7 enero 2016.

44. Francisco E. López Soldevila et al., op. cit., p. 162.

45. Conde de Roche, Catálogo de las esculturas que hizo Don Roque López, discípulo de Salzillo, Murcia, Diario de Murcia, 1889, p. 3. 
comuniones» para que «Dios le dispensara su gracia para el acierto» al realizar la «efigie de Cristo nuestro señor» y de la Virgen ${ }^{46}$. Las imágenes religiosas eran objetos sagrados y remitían a quienes eran ejemplo de vida para el creyente, en la consideración de que no había divinidad en ellas sino que remitían a lo que representaban, como señaló el Concilio de Trento en el decreto de 1563. El fiel las veneraba y buscaba su protección y taumaturgia, despertaban fervor y empatía y, pese a lo dispuesto en concilios y sínodos, continuó el uso supersticioso de las mismas ${ }^{47}$.

Nicolás de Bussy, escultor oriundo de Estrasburgo que desarrolló su trayectoria profesional en España, introdujo una cédula en la vera efigie que realizó en 1700 de San Francisco Javier para los jesuitas de Murcia, como acto de contrición y petición de perdón a Dios como «humilde esclavo» y solicitud de «mayor perfección» y acierto para hacer las imágenes ${ }^{48}$. Más extenso es el mensaje de 27 de diciembre de 1693, que situó en el Cristo de la Sangre. Le pedía estar entre los bienaventurados tras la muerte y, en vida, que le favoreciese «de ciencia para las cosas de estas imágenes vuestras que hago decía- para consuelo de vuestros devotos y que todas las oraciones que a ellas os fuesen presentadas os obligue -señalaba- a esta mi intención ${ }^{49}$, reiterando que le librase «de los enemigos del alma» y le ayudase e iluminase en la ciencia. Expresaba su amor a Dios, suplicaba con insistencia que llevase al cielo a los pobres y a sus parientes, consignando a sus padres, "hermanos y hermanas», su mujer y «la pobre esclava» que había comprado, pidiendo la sacase «con una centella» de gracia "de la oscuridad turquesca» y se bautizase para alcanzar la salvación. Concluía con palabras deprecatorias, previas a la fecha y firma: «Esto: todo repetido con estas letras, os suplico postrado, con los demás beneficios de vuestro Divino Amor y Misericordia, recibiendo vuestra santa bendición, depositándolo en esta Divina Imagen ${ }^{50}$.

46. Antonio Palomino, El Museo Pictórico y escala óptica. III. El Parnaso español pintoresco y laureado, Madrid, Aguilar, 1988, p. 115.

47. Palma Martínez-Burgos García, Ídolos... op. cit. Alfonso Rodríguez G. de Ceballos, «Tipos, usos y abusos de las imágenes sagradas», en R. Fernández Gracia (coord.), Pulchrum: scripta varia in honorem $M^{a}$ Concepción García Gainza, Pamplona, Universidad de Navarra, 2011, p. 718-725. Xavier Bray (ed.), op. cit. Ronda Kasl (ed.), Sacred Spain: Art and Belief in the Spanish World, cat. exp., New Haven/London, Yale University Press, 2009.

48. La nota estaba muy deteriorada (M. Carmen Sánchez-Rojas Fenoll, El escultor Nicolás de Bussy, Murcia, Universidad de Murcia, 1982, p. 123). En otros contextos Didi-Huberman ha estudiado el juego de palabras que implica al mismo tiempo ser humilde y servir -ser esclavodel ser poderoso, en este caso Dios (op. cit., p. 79).

49. José Sánchez Moreno, «Don Nicolás de Bussy escultor. Nuevos datos sobre su personalidad", Anales de la Universidad de Murcia, no II, 1943, p. 121-149.

50. De la cédula del Cristo se hizo copia mecanografiada en 1949 (recogida en Vicente Montojo Montojo et al., Un escultor europeo en España. Tercer centenario de su muerte (17062006), Murcia, Real Academia de Bellas Artes de Santa María de la Arrixaca, 2006, p. 186-187. Mi agradecimiento a Ana Baquero y Antonio Jiménez Micol por las sugerencias realizadas. 


\section{CONSIDERACIÓN FINAL}

Frente a las escrituras expuestas, las escrituras inexpuestas confieren a la obra de arte un valor ańadido. En ocasiones, permiten efectuar un acercamiento más certero a la pieza y al complicado mundo de las relaciones humanas, religiosidad y creación artística. La escultura, que es simulacro y ficción, presta sus entrañas para que habiten mensajes que se vinculan inequívocamente a la obra, que se erige en espacio de libertad para declarar cuanto se quiera y guardar la memoria de maestros y benefactores.

Cabría establecer tres categorías de mensajes: devocionales, conmemorativos y reivindicativos. Estas prácticas de escritura tienen el denominador común de haber sido generadas durante el proceso de realización de las esculturas religiosas y, las cédulas, escondidas unas veces clandestinamente y otras con conocimiento de clientes y artistas. Se trata de un fenómeno generalizado, que presenta rasgos diferenciales en el barroco hispánico, sobre el que queda mucho por saber y notas por descubrir. 
